\title{
THE EFFECT OF NaOH CONCENTRATION IN DELIGNIFICATION PROCESS ON MICROCRYSTALLINE CELLULOSE FROM GREEN ALGAE (Cladophora sp.) AS THE RENEWABLE MARINE PRODUCT
}

\section{PENGARUH KONSENTRASI NaOH PADA PROSES DELIGNIFIKASI TERHADAP SELULOSA MIKROKRISTAL DARI ALGA HIJAU (Cladophora sp.) SEBAGAI PRODUK BAHARI TERBARUKAN}

\author{
I Gusti Ngurah Jemmy Anton Prasetia*), Shelia Deviana, Trisna Damayanti, \\ Angga Cahyadi, I Made Agus Gelgel Wirasuta
}

Pharmacy Study Program, FMIPA, Udayana University, Jimbaran, Bali, Indonesia

Received February 27, 2018; Accepted August 28, 2018

\begin{abstract}
Research on marine natural resources as an excipient material of pharmaceutical product is still rare. One of the marine products is the green algae, Cladophora sp. High cellulose content causes Cladophora sp. which can be used as an alternative material of microcrystalline cellulose (SM). There are two stages to produce SM, namely delignification and hydrolysis. Delignification is the process of removing the lignin of complex compounds. The delignification process is carried out chemically in alkaline situation using a $\mathrm{NaOH}$ solution which dissolves lignin, carbohydrates, organic acids, and resins so that cellulose is released from its bonds. This is important because the presence of lignin may inhibit acid penetration prior to hydrolysis. Therefore, the purpose of this study is to investigate the effect of delignification by using $\mathrm{NaOH}$ solution at various concentrations $(2,4$, and $6 \%)$ to cellulose content and physical character of microcrystalline cellulose from Cladophora sp. (SMC). In the hydrolysis process, $5 \% \mathrm{HCl}$ solution was used. SMCs of various concentrations of $\mathrm{NaOH}$ were observed and the cellulose levels included alpha, beta and gamma levels. While the physical character observation is done on Scanning Electron Microscopy (SEM) test. Based on the cellulose content, the higher the concentration of NaOH used, the higher the alpha cellulose will increase. The opposite result occurs on the measurement of beta and gamma cellulose. Based on SEM test, it appears that there is no effect of increasing NaOH concentration on physical character of SMC.
\end{abstract}

Keywords: Cladophora sp., delignification, microcrystalline cellulose, $\mathrm{NaOH}, \mathrm{SEM}$

\begin{abstract}
ABSTRAK
Penelitian mengenai pemanfaatan sumber daya alam bahari sebagai bahan eksipien sediaan farmasi masih jarang. Salah satu produk bahari adalah alga hijau Cladophora sp. Kandungan selulosa yang cukup tinggi menyebabkan Cladophora sp. dapat dijadikan sebagai alternatif bahan baku pembuatan selulosa mikrokristal (SM). Pembuatan SM dilakukan melalui dua tahapan yaitu proses delignifikasi dan hidrolisis. Delignifikasi merupakan proses penghilangan struktur lignin dari suatu senyawa kompleks. Proses delignifikasi dilakukan secara kimia dalam keadaan alkali menggunakan larutan $\mathrm{NaOH}$ yang berfungsi melarutkan lignin, karbohidrat, asam organik, dan resin sehingga selulosa terlepas dari ikatannya. Hal ini penting dilakukan karena adanya lignin dapat menghambat penetrasi asam sebelum dilakukan proses hidrolisis. Berdasarkan hal tersebut, tujuan penelitian ini adalah untuk mengetahui pengaruh penggunaan larutan $\mathrm{NaOH}$ pada berbagai konsentrasi (2; 4; dan 6\%) terhadap kadar selulosa serta karakter fisik selulosa mikrokristal dari Cladophora sp. (SMC). Dalam proses hidrolisis, digunakan larutan $\mathrm{HCl} 5 \%$. SMC dari berbagai konsentrasi $\mathrm{NaOH}$ dilakukan pengamatan kadar selulosa yang meliputi kadar alfa, beta dan gamma. Sedangkan pengamatan karakter fisik dilakukan berdasarkan pengujian Scanning Electron Microscopy (SEM). Ditinjau dari kadar selulosa, semakin tinggi konsentrasi $\mathrm{NaOH}$ yang digunakan, kadar alfa semakin meningkat. Hasil sebaliknya terjadi pada pengukuran kadar beta dan gamma selulosa. Berdasarkan pengamatan melalui uji SEM tampak bahwa tidak ada perbedaan karakteristik fisik seiring dengan peningkatan konsentrasi $\mathrm{NaOH}$ yang digunakan.
\end{abstract}

Kata kunci: Cladophora sp., delignifikasi, selulosa mikrokristal, NaOH, SEM

*Corresponding author: I Gusti Ngurah Jemmy Anton Prasetia

Email: ngurah_jemmy@yahoo.com 


\section{INTRODUCTION}

One example of Green algae, Cladophora sp., has a high growth rate. Uncontrolled growth can lead to "algae blooms" which can cause water ecosystem pollution characterized by changes in water color and produce unpleasant odor (Sze, 1993).

Mihranyan (2011) states that Cladophora sp. contains high cellulose. Cellulose is the main raw material of microcrystalline cellulose (SM). The dissolution of cellulose in strong alkali will produce alpha cellulose. The higher level of alpha cellulose will cause the higher purity level of microcrystalline cellulose that is produced (Gunam et al., 2010). The utilization of Cladophora sp. as the main raw source of cellulose has the advantage because this type of algae has not been widely used.

To be able to dissolve cellulose, lignin contained in the plant cell wall should be destroyed first. This process is called delignification. The current research on delignification process was carried out on rice straws. Prasetia et al. (2015), state that the use of $\mathrm{NaOH}$ solution in a delignification process can dissolve cellulose in to produce alpha cellulose. In the Mansur variety rice straws, the Balinese local rice, the use of $7.5 \%$ of $\mathrm{NaOH}$ is able to purify cellulose up to $82.96 \%$. $15 \%$ of $\mathrm{NaOH}$ is required for rice straws IR-64 variety until $98.0 \%$ of alpha cellulose is obtained (Prasetia and Dewantara Putra, 2015). Different result is obtained by Dewantara Putra et al., 2016, where 5\% of $\mathrm{NaOH}$ is required for the delignification process of Balinese local red rice straw. The different characteristics of plant cell wall will cause different solution of $\mathrm{NaOH}$ in the delignification process.

Based on this research, the researcher would like to examine the influence of using $\mathrm{NaOH}$ solution on various concentrations $(2 ; 4$; and $6 \%)$ to the cellulose content and the physical characteristics of microcrystalline cellulose from Cladophora sp. (SMC).

\section{METHODS}

\section{Material}

Green algae of Cladophora sp. is obtained in Jimbaran coastal area in Badung Regency. The materials are $\mathrm{NaOH}$ (Pharmaceutical Grade, Bratachem), $\mathrm{HCl}$ (Pharmaceutical Grade, Bratachem), indicator of Ferroin (Pharmaceutical Grade, PT. Nusa Indah), potassium dichromate (Pharmaceutical Grade, Merck), ferrous ammonium sulfate (Pharmaceutical Grade, Merck) and distilled water (Pharmaceutical Grade, Waterone).

\section{Equipment}

The equipment used includes an analytical balance $\left(\right.$ Adam $^{\circledR}$ AFP-360L), a desiccator, $\mathrm{pH}$ meter (Oakton pH 510 series), glass tools, mesh 60, a water bath (Memmert), an oven (Binder), SEM test equipment (JEOL-2200).

\section{Sample Collection}

The sample that is used is Cladophora sp. algae obtained in the coastal area in Jimbaran, Badung regency, Bali.

\section{Plant Identification}

The determination process was conducted in the Laboratory of the Department of Pharmacy Biology, Gadjah Mada University, Yogyakarta.

\section{Sample Processing}

The sample is sorted then baked in the oven at $60^{\circ} \mathrm{C}$ for 24 hours.

\section{Delignification Process}

One gram of sample is dissolved in $12 \mathrm{ml}$ of $\mathrm{NaOH}$ into various concentrations of $\mathrm{NaOH}(2 ; 4$; and $6 \%$ ) at $60^{\circ} \mathrm{C}$ for 24 hours and then the result is filtered. The pulp is then separated and washed with distilled water until a neutral $\mathrm{pH}$ is obtained. Afterwards, the desiccation is conducted at room temperature for 24 hours (Mihranyan, 2011).

\section{Hydrolysis Process}

One gram of each formula is then soaked in $20 \mathrm{ml}$ of $5 \%$ of $\mathrm{HCL}$ at $92^{\circ} \mathrm{C}$. After that, let the pulp settle overnight at the room temperature. The pulp obtained is then filtered and washed with distilled water until the neutral $\mathrm{Ph}$ is reached. After the desiccation process is conducted at $60^{\circ} \mathrm{C}$ for 12 hours, the sample is sieved with a 60mesh sieve (Mihranyan, 2011).

\section{Microcrystalline Cellulose Evaluation}

SMC from various concentrations of $\mathrm{NaOH}$ is observed for identifying the cellulose content which includes alpha, beta and gamma content based on the method listed in the Indonesian National Standard (SNI) 2009. Meanwhile, the physical character observation is conducted based on the Scanning Electron Microscopy (SEM) test. 


\section{RESULT AND DISCUSSION \\ Cellulose Content Test}

Cellulose content test was conducted by using the titration method which is marked by the formation of purple color (SNI, 2009). Alphacellulose is a long-chain cellulose with 600-1500 degree of polymerization and insoluble in $17.5 \%$ of $\mathrm{NaOH}$ solution or strong alkaline solution. Alpha-cellulose is used to determine the level of cellulose purity. Beta-cellulose is a short-chain cellulose with 15-90 degree of polymerization, can be dissolved in $17.5 \%$ of $\mathrm{NaOH}$ or strong base, can precipitate when it neutralized. Gammacellulose is a short-chain cellulose with polymerization degree less than 15 , can be dissolved in $17.5 \%$ of $\mathrm{NaOH}$ or strong base and the main content is hemicellulose (Sumada et al., 2011). Gamma-cellulose test aims to identify hemicellulose contained in microcrystalline cellulose. The content of cellulose can be seen in the Table 2.

Figure 1 shows that alpha cellulose obtained is significantly increasing with the increasing $\mathrm{NaOH}$ that is used in the delignification process. However, the content of beta and gamma-cellulose produced is decreasing. The highest content of alpha-cellulose is produced in SMC-6. Conversely, with the same formula, the lowest price of beta and gamma-cellulose is obtained when compared to other SMCs.

Based on these data, an increase in $\mathrm{NaOH}$ concentration can increase alpha-cellulose content on microcrystalline cellulose produced. The higher concentration used, the higher the ability to damage lignin and cellulose. In addition, it also can cause the cellulose to be easily hydrolyzed so that the content of alpha-cellulose is getting higher
(Gunam et al., 2010). The use of strong alkaline, $\mathrm{NaOH}$, will be able to break the structure of hemicellulose and dissolve it. The more $\mathrm{NaOH}$ is used, the more hemicellulose content can be dissolved so that alpha-cellulose content increases.

\section{Scanning Electron Microscopy (SEM) Test}

The analysis of physical characteristics and surface morphology of a sample can be observed by using Scanning Electron Microscopy (SEM) method. The result can be seen in Figure 2. SEM from SMC-2, SMC-4 and SMC-6 shows that the fibrils intertwined with a smooth surface. It indicates that the morphologies produced are similar (Camacho et al., 2011). Therefore, in terms of physical characteristics, the increase in $\mathrm{NaOH}$ concentration has no significant effect.

Table I. NaOH Variations on Delignification Process in Making Microcrystalline Cellulose Cladophora sp.

\begin{tabular}{cc}
\hline Formula & NaOH Concentration $(\%)$ \\
\hline SMC-2 & 2 \\
SMC-4 & 4 \\
SMC-6 & 6 \\
\hline
\end{tabular}

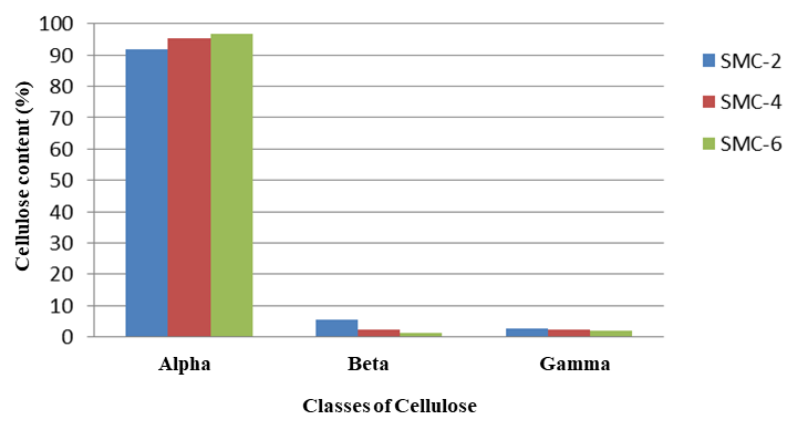

Figure 1. Graph of cellulose content in various SMCs

Table II. Observation Result of Cellulose Content in Various SMC Formula

\begin{tabular}{cccc}
\hline \multirow{2}{*}{ Formula } & \multicolumn{3}{c}{ Cellulose Content (\%) } \\
\cline { 2 - 4 } & Alpha & Beta & Gamma \\
\hline SMC-2 & $91.75 \pm 0.55$ & $5.60 \pm 0.49$ & $2.65 \pm 0.06$ \\
SMC-4 & $95.41 \pm 0.59$ & $2.33 \pm 0.56$ & $2.25 \pm 0.08$ \\
SMC-6 & $96.68 \pm 0.36$ & $1.32 \pm 0.24$ & $2.00 \pm 0.19$ \\
\hline
\end{tabular}
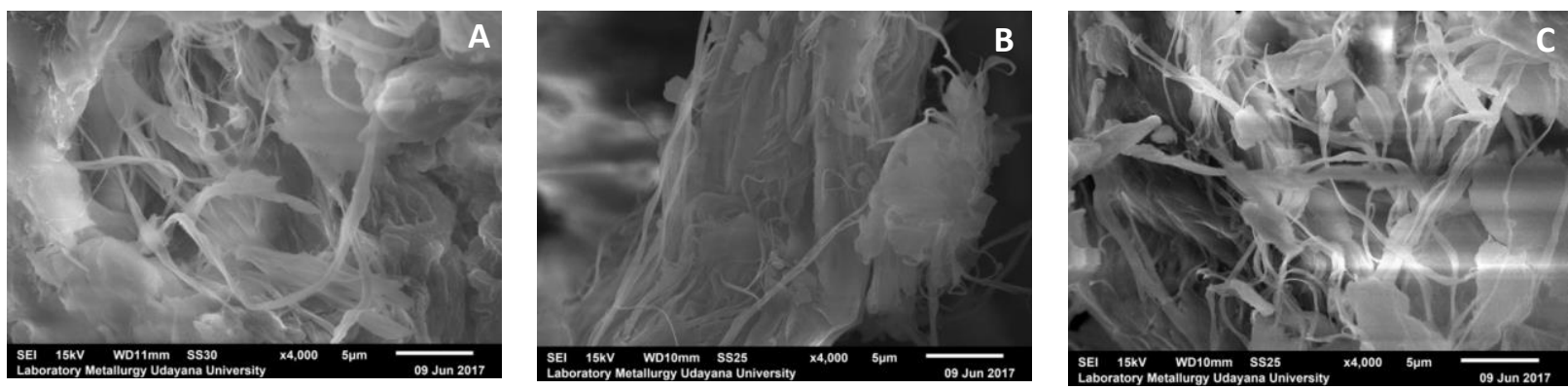

Figure 2. The SEM test result with 4000 times enlargement with various $\mathrm{SMCs}(\mathrm{A}=\mathrm{SMC}-2 ; \mathrm{B}=\mathrm{SMC}-4$; and $\mathrm{C}=\mathrm{SMC}-6)$ 


\section{CONCLUSION}

Various concentrations of $\mathrm{NaOH}$ in the delignification process on Cladophora sp. affect the cellulose content that is produced but it does not affect the physical characteristic formed. This finding is based on the result of cellulose content test and SEM test.

\section{ACKNOWLEDGEMENT}

Thank you for the LPPM of Udayana University for providing financial assistance to implement this research.

\section{REFERENCES}

Camacho, D.H., Gerongay, S.R.C., and Macalinao, J.P.C. 2013. Cladophora CellulosePolyaniline Composite for Remediation of Toxic Chromium (VI). Cellulose Chemistry and Technology, 47(1-2), 125-132.

Dewantara Putra, I.G.N., Prasetia, I.G.N., Aparigraha, G.A. 2016. Karakteristik MCC Jerami Padi Beras Merah Dengan Metode Delignifikasi $\mathrm{NaOH}$ 5\%. Jurnal Farmasi Udayana. 5(1), 20-23.

Gunam, I.B.W., Ketut B., and I Made Y.S.G. 2010. Pengaruh Perlakuan Delignifikasi Dengan Larutan $\mathrm{NaOH}$ dan Konsentrasi Substrat Jerami Padi Terhadap Produksi Enzim Selulase Dari Aspergilus niger NRRL A-II, 264. Jurnal Biologi. 14(1), 55-61.
Mihranyan, A. 2011. The Cellulose From Cladophorales Green Algae: From Environmental Problem to High-Tech Composite Materials. Journal of Applied Polymer Science. 119, 2449-2460.

Prasetia, I G. N., Dewantara Putra, I.G.N., Arsana, D.A.M.I.P.S., dan Merlina Prabayanti, N.P. 2015. Studi Karakteristik Farmasetis Mikrokristalin Selulosa dari Jerami Padi Varietas Lokal Bali. Jurnal Sains Materi Indonesia, 17(3), 119-123.

Prasetia, I.G.N., and Dewantara Putra, I.G.N. 2015. Pengaruh Konsentrasi $\mathrm{NaOH}$ Terhadap Pembentukan Alfa Selulosa Pada Pembuatan Selulosa Mikrokristal Dari Jerami Padi Varietas IR64. Prosiding Seminar Nasional Sains dan Teknologi (Senastek) 2015. Bali: Universitas Udayana.

Standar Nasional Indonesia (SNI). 2009. PulpCara Uji Kadar Selulosa Alfa, Beta, dan Gamma. Jakarta: Badan Standardisasi Indonesia.

Sumada, K., Tamara, P.E., and Alqani, F. 2011. Isolation Study of Efficient $\alpha$-Cellulose From Waste Plant Stem Manihot Esculenta crantz. Jurnal Teknik Kimia. 5(2), 434-438.

Sze, P. 1993. A Biology of the Algae 2nd Ed. Iowa: Wm. C. Brown Publishers. 